\title{
Cell line access to revolutionize the biosimilars market
}

\section{[version 1; peer review: 2 approved]}

\section{Dzintars Gotham (iD)}

\author{
Independent Researcher, Boston, MA, USA
}

V1 First published: 03 May 2018, 7:537

https://doi.org/10.12688/f1000research.14808.1

\section{Open Peer Review \\ Approval Status \\ 1 \\ 2 \\ version 1 \\ 03 May 2018

$\checkmark$

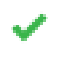 \\ 1. Amit Misra ID, CSIR- Central Drug Research \\ Institute (CDRI), Lucknow, India \\ 2. François Bocquet, University Public \\ Hospitals of Paris, Paris, France}

Any reports and responses or comments on the article can be found at the end of the article. needed to bring a non-originator biologic to market. This system would allow far greater price reductions for biologics after the expiry of monopoly rights (e.g. patents), while maintaining the monopoly rights used to incentivize drug development.

\section{Keywords}

biologics, biosimilars, economics, pharmacology, access to medicines, regulatory policy, pharmaceutical policy, health policy

\section{Corresponding author: Dzintars Gotham (dzintarsgotham@gmail.com)}

Author roles: Gotham D: Conceptualization, Formal Analysis, Investigation, Methodology, Writing - Original Draft Preparation, Writing Review \& Editing

Competing interests: No competing interests were disclosed.

Grant information: The author(s) declared that no grants were involved in supporting this work.

Copyright: ( 2018 Gotham D. This is an open access article distributed under the terms of the Creative Commons Attribution License, which permits unrestricted use, distribution, and reproduction in any medium, provided the original work is properly cited.

How to cite this article: Gotham D. Cell line access to revolutionize the biosimilars market [version 1; peer review: 2 approved] F1000Research 2018, 7:537 https://doi.org/10.12688/f1000research.14808.1

First published: 03 May 2018, 7:537 https://doi.org/10.12688/f1000research.14808.1 


\section{Introduction}

The importance of biologics in both clinical and economic terms continues to grow ${ }^{1}$. At the same time, biologics are notoriously expensive, and challenges in affordability remain even after the expiry of monopoly rights. Price reductions seen with biosimilars are in general smaller than for small molecule medicines and have a higher starting point, with originator prices typically being in the tens of thousands of dollars. Even after originator patent expiry, biosimilars strain health budgets and remain inaccessible for many patients globally ${ }^{2,3}$.

\section{Biologic monopoly rights and biosimilar development}

Biologic drugs are large, complex molecules whose exact composition is often not fully known, and the exact manufacturing process used is closely related to safety and efficacy - including the specific growth media, post-translational modifications, and the purification processes used. Details on these manufacturing processes are trade secrets and are thus inaccessible to competitors for a potentially indefinite period. Moreover, the cell line that produces the originator product remains the property of the originator like any other physical asset, and almost all information about the cell line remains a trade secret. Consequently, biosimilar manufacturers have to undertake laborious reverseengineering work and phase 3 trials to demonstrate that their product is not different to the originator's in a clinically significant way.

This represents a significant duplication of efforts and means that the barriers to competition in biologics far exceed the time-limited monopoly rights - granted through patents, market exclusivity, and data exclusivity - that attempt to legislatively balance the need to incentivize drug development against the social benefit of competition-driven price reductions. These barriers translate to higher costs: While the exact numbers are not publicly available, the cost of bringing a biosimilar to market in the US has been estimated to be \$100-200 million, compared to \$1-5 million for small-molecule medicines ${ }^{4}$.

Aside from development expenditures, what are the inherent costs of manufacturing a biosimilar once it has been approved? For monoclonal antibodies - the most common type of biologic drug - they are reported to range US\$20,000-300,000 per kilogram of active ingredient, which includes capital investments in manufacturing facilities and overheads ${ }^{5,6}$. Multiplying these estimates by per-treatment dosage, the costs of manufacturing alone appear to represent only a small proportion of the price $0.001-6 \%$ of current lowest prices in the US and $0.004-14 \%$ of prices in the UK, for blockbuster biologics (Table 1). Even in India, where the costs of bringing a biosimilar to market are

Table 1. Current prices of selected blockbuster biologics and cost of manufacture for the active ingredient. The table illustrates the large differences between current prices and the cost of manufacturing the active ingredient, for blockbuster biologic medicines.

\begin{tabular}{|c|c|c|c|c|c|c|}
\hline \multirow[t]{2}{*}{ Medicine } & \multirow{2}{*}{$\begin{array}{l}\text { Example } \\
\text { indication }\end{array}$} & \multirow{2}{*}{$\begin{array}{l}\text { Duration of treatment } \\
\text { used for comparison } \\
\text { (corresponding } \\
\text { dosage in } \mathrm{mg} \text { ) }\end{array}$} & \multicolumn{3}{|c|}{ Lowest available price (USD) } & \multirow{2}{*}{$\begin{array}{l}\text { Cost of } \\
\text { manufacturing the } \\
\text { active ingredient }\end{array}$} \\
\hline & & & $\begin{array}{l}\text { US } \\
\text { (Veterans } \\
\text { Affairs) }\end{array}$ & UK & India & \\
\hline Adalimumab & $\begin{array}{l}\text { Rheumatoid } \\
\text { arthritis }\end{array}$ & 2-week cycle (40mg) & $\$ 707$ & $\$ 482$ & $\$ 385^{*}$ & $\$ 1-12$ \\
\hline Alemtuzumab & $\begin{array}{l}\text { Relapsing- } \\
\text { remitting multiple } \\
\text { sclerosis }\end{array}$ & $\begin{array}{l}\text { 2-year treatment } \\
\text { course }(96 \mathrm{mg})\end{array}$ & $\$ 122,477$ & $\$ 77,213$ & $\mathrm{~N}$ & $\$ 2-29$ \\
\hline Bevacizumab & $\begin{array}{l}\text { Metastastic } \\
\text { colorectal cancer }\end{array}$ & 2-week cycle (700mg) & $\$ 3,694$ & $\$ 2,216$ & $\$ 1,077^{*}$ & $\$ 14-210$ \\
\hline Etanercept & $\begin{array}{l}\text { Rheumatoid } \\
\text { arthritis }\end{array}$ & $\begin{array}{l}1 \text { month of treatment } \\
\text { (200mg) }\end{array}$ & $\$ 2,019$ & $\$ 3,526^{\star}$ & $\$ 639^{*}$ & $\$ 4-60$ \\
\hline Infliximab & Crohn's disease & $\begin{array}{l}1 \text { maintenance dose } \\
\text { (350mg) }\end{array}$ & $\$ 1,753^{\star}$ & $\$ 1,808^{*}$ & $\$ 1,723^{*}$ & $\$ 7-105$ \\
\hline Ranibizumab & $\begin{array}{l}\text { Wet age- } \\
\text { related macular } \\
\text { degeneration }\end{array}$ & $\begin{array}{l}1 \text { intravitreal injection } \\
(0.5 \mathrm{mg})\end{array}$ & $\$ 1,300$ & $\$ 229$ & $\$ 57^{*}$ & $\$ 0.01-0.15$ \\
\hline Rituximab & $\begin{array}{l}\text { Non-Hodgkin's } \\
\text { lymphoma }\end{array}$ & 1 cycle $(650 \mathrm{mg})$ & $\$ 3,685$ & $\$ 1,400^{*}$ & $\$ 711^{*}$ & $\$ 13-195$ \\
\hline Trastuzumab & $\begin{array}{l}\text { HER2-positive } \\
\text { breast cancer }\end{array}$ & 3-week cycle (420mg) & $\$ 2,878$ & $\$ 1,172$ & $\$ 861^{*}$ & $\$ 8-126$ \\
\hline
\end{tabular}

*Biosimilar.

Details on indications, dosage, and price sources are available in Supplementary File 1.

Prices for the UK may not include confidential rebates. 
considered to be significantly lower, and all the prices shown are for biosimilars, the estimated cost of manufacturing would represent only $0.02-27 \%$ of the price.

It thus appears that if the need for investments in reverse-engineering and phase 3 trials were removed, price reductions for biologic therapies following the expiry of monopoly rights could be far greater than at present.

\section{A proposal: cell line access}

In order to lower the barriers to bringing follow-on biologic products to market, prospective manufacturers should be given access to the originator cell lines and detailed descriptions of manufacturing processes.

To achieve this, originator biologics manufacturers could be required to submit a living vial of the cell line used to manufacture the product upon regulatory approval, to be stored by the relevant regulatory body. Cloned cell lines would then be shared with prospective manufacturers, prior to the expiry of the originator's monopoly rights. Detailed descriptions of originators' manufacturing processes, which are already submitted to regulators confidentially, could be made publicly available?

This system would allow originators to fully enjoy legislatively granted time-limited monopoly rights, while avoiding arguably unnecessary and duplicative drug development and enabling maximal competition as soon as monopoly rights expire.

I refer to this proposed system as 'cell line access' and biologics developed through this system as CLA biologics. The non-profit group Knowledge Ecology International has previously made a similar proposal ${ }^{8}$, and Price and Rai have proposed that incentive mechanisms could be set up to encourage the disclosure of trade secrets pertaining to manufacturing processes $^{7}$

\section{The benefits of cell line access}

First, access to cell lines and production processes would dramatically reduce the financial and time investments required for developing a non-originator biologic product. The prices of CLA biologics would be expected to be substantially lower than the price reductions currently seen for biosimilars, both due to increased competition and lower costs.

Second, there would be clinical benefits, as CLA biologics could be expected to automatically be interchangeable with the originator product, rather than only 'similar'.
Third, biopharmaceutical science more broadly would benefit, especially if access to cell lines and manufacturing processes were extended also to research institutions.

\section{Adapting existing regulatory procedures}

The potential benefits of cell line access would in large part depend on regulators being satisfied that if an identical cell line and manufacturing process are used, phase 3 trials would not be necessary, and approval could be granted based on demonstration of equivalence by other methods.

Differences between CLA biologics and the reference (originator) product would be expected to be of the same magnitude as batch-to-batch variation in the originator's product. As originators regularly make slight changes to their manufacturing process, regulatory procedures are already in place to ensure that these changes do not jeopardize efficacy or safety ${ }^{9}$, for which in vitro analytical tools are nearly always sufficient ${ }^{9,10}$. These established procedures could be adapted to the task of ensuring that CLA biologics are not substantially different from the originator product.

Similarly, the change of manufacturer, while preserving the cell line and manufacturing processes used, is comparable to situations where originator companies use contract manufacturing organizations or regional manufacturing partners, an increasingly common practice ${ }^{11}$.

\section{Conclusion}

Enabling prospective non-originator manufacturers to access originator cell lines and manufacturing processes could remove the need for laborious reverse-engineering and duplicative clinical trials. This would allow full enjoyment by originators of the monopoly rights granted through patents and other protections, while allowing far greater price reductions upon expiry of monopoly rights. While significant political challenges would be expected, this proposed mechanism could be explored further in terms of the potential economic and health impacts, and practical options for implementation.

\section{Data availability}

No data is associated with this article.

\section{Grant information}

The author(s) declared that no grants were involved in supporting this work.

\section{Acknowledgements}

The author thanks Melissa J Barber for their thoughtful discussions of the ideas proposed in the article.

\section{Supplementary material}

Supplementary File 1. This document describes the data sources for the US, UK, and India prices given in Table 1, as well as assumptions regarding dosage. 
1. Belloni A, Morgan D, Paris V: Pharmaceutical Expenditure And Policies. OECD Health Working Papers, 2016.

Publisher Full Text

2. Blackstone EA, Fuhr JP: The economics of biosimilars. Am Health Drug Benefits. 2013; 6(8): 469-478.

PubMed Abstract | Free Full Text

3. QuintilesIMS: The Impact of Biosimilar Competition in Europe. 2017; Accessed April 12, 2018.

Reference Source

4. Federal Trade Commission Report: Emerging Health Care Issues: Follow-on Biologic Drug Competition. 2009; Accessed April 12, 2018.

Reference Source

5. Kelley B: Industrialization of mAb production technology: the bioprocessing industry at a crossroads. mAbs. 2009; 1(5): 443-452.

PubMed Abstract | Publisher Full Text | Free Full Text

6. Liu C, Morrow J, eds: Biosimilars of Monoclonal Antibodies: A Practical Guide to Manufacturing, Preclinical, and Clinical Development. Hoboken, New Jersey:
John Wiley \& Sons, Inc; 2017.

Publisher Full Text

7. Price WN 2nd, Rai AK: Drug Development. Are trade secrets delaying biosimilars? Science. 2015; 348(6231): 188-189.

PubMed Abstract | Publisher Full Text

8. Singhroy D: Policies about access to knowledge, data and materials to make it easier to make biosimilar drugs. May 2, 2017. Presented at the WHO Consultation on Biosimilar Drugs.

9. McCamish M, Woollett G: Worldwide experience with biosimilar development. mAbs. 2011; 3(2): 209-217.

PubMed Abstract | Publisher Full Text | Free Full Text

10. U.S. Food and Drug Administration: Guidance for Industry: Q5E Comparability of Biotechnological/Biological Products Subject to Changes in Their Manufacturing Process. Accessed March 16, 2018.

Reference Source

11. The Hindu Business Line: Emcure to make, market Roche products. Accessed March 25, 2018.

Reference Source 


\section{Open Peer Review}

\section{Current Peer Review Status:}

\section{Version 1}

Reviewer Report 12 July 2018

https://doi.org/10.5256/f1000research.16117.r34194

(C) 2018 Bocquet F. This is an open access peer review report distributed under the terms of the Creative Commons Attribution License, which permits unrestricted use, distribution, and reproduction in any medium, provided the original work is properly cited.

\section{François Bocquet}

Pharmacy Department, General Agency of Equipments \& Health Products, University Public Hospitals of Paris, Paris, France

This opinion paper is interesting. My first concern is the presentation of the production costs of the active substances.

Indeed, only reasoning (ie for each molecule) in proportion to the Kelley figure of $\$ 20,000$ to $\$ 300,000$ per kilogram of active ingredient (equivalent to $\$ 0.02-0.3$ per milligram) without having any idea of the real cost for each molecule can be misleading, and is not very satisfactory. These data being confidential, thank you to the authors to specify this in the legend of the table and not only in the supplementary material.

Even if the idea proposed by the authors is interesting intellectually, it clashes with the respect of the patent right. It should be emphasized more in the paper.

\section{References}

1. Bocquet F, Loubière A, Fusier I, Cordonnier AL, et al.: Competition Between Biosimilars and Patented Biologics: Learning from European and Japanese Experience.Pharmacoeconomics. 2016; 34 (11): 1173-1186 PubMed Abstract | Publisher Full Text

Is the topic of the opinion article discussed accurately in the context of the current literature?

Yes

Are all factual statements correct and adequately supported by citations? Yes

Are arguments sufficiently supported by evidence from the published literature? Yes 


\section{Are the conclusions drawn balanced and justified on the basis of the presented arguments? Yes}

Competing Interests: No competing interests were disclosed.

\section{I confirm that I have read this submission and believe that I have an appropriate level of expertise to confirm that it is of an acceptable scientific standard.}

Reviewer Report 31 May 2018

https://doi.org/10.5256/f1000research.16117.r34142

(C) 2018 Misra A. This is an open access peer review report distributed under the terms of the Creative Commons Attribution License, which permits unrestricted use, distribution, and reproduction in any medium, provided the original work is properly cited.

\section{Amit Misra}

CSIR- Central Drug Research Institute (CDRI), Lucknow, Uttar Pradesh, India

My compliments to the author for this potentially revolutionary idea. However, solely addressing the drug regulator and enjoining it to implement cell line access (CLA) is, in my view, a sub-optimal strategy. First, the regulator may very often cite lack of capacity to preserve and distribute vials containing live cells. Issues related to refusal of access (e.g., on grounds of lack of competence or non-compliance with Good Manufacturing Practices) to applicants would require the regulator to expend a great deal of time and effort in deciding who gets a vial and who doesn't. Last, the innovator is denied any say in the dissemination of the innovation for public good if the drug regulator is the sole arbiter of CLA. With competitive marketing practices being what they are, it is not inconceivable that a competitor may choose to acquire CLA, only to generate a sub-optimal product that could then be faulted for poor performance to build a negative perception about the innovator.

In my view, it would be important to invoke a "multi-stakeholder initiative" (MSI) involving drug regulators, civil society organizations working on access to medicines, and corporations that discover and produce biologics to ensure CLA worldwide. "Corporate Social Responsibility" (CSR) guidance and legislation in various countries would provide incentive to corporations to join such an MSI. A transparent process whereby applicants requesting access could be assessed and granted (or refused) CLA would be, in my view, a more sustainable strategy. Originators could then also "hand-hold" successful applicants through the process of adapting the cell lines to their specific bioreactors and downstream processing equipment. Of course, drug regulators would be required to notify CLA as mandatory after the monopoly period is over, while granting marketing permission (as also retrospectively for off-patent biologics).

I would like to request the author to consider the feasibility and sustainability of the CLA initiative before concluding that it is sufficient for the drug regulator to require originators to share cell lines and manufacturing processes as a "practical option for implementation."

Finally, although it is beyond the scope of the present article, I would like to suggest that the author may touch upon the regulatory requirement of "sameness" in respect of biologics, and whether Phase 3 "comparative" clinical trials actually make sense. There is extensive literature on these aspects, including two articles cited below. 


\section{References}

1. Minghetti $P$, Rocco $P$, Schellekens $H$ : The constrained prescription, interchangeability and substitution of biosimilars. Nature Biotechnology. 2015; 33 (7): 688-689 Publisher Full Text 2. Schellekens H, Smolen J, Dicato M, Rifkin R: Safety and efficacy of biosimilars in oncology. The Lancet Oncology. 2016; 17 (11): e502-e509 Publisher Full Text

Is the topic of the opinion article discussed accurately in the context of the current literature?

Yes

Are all factual statements correct and adequately supported by citations? Partly

Are arguments sufficiently supported by evidence from the published literature? Yes

Are the conclusions drawn balanced and justified on the basis of the presented arguments? Partly

Competing Interests: I have received travel funding and hospitality from Médecins Sans Frontières, All India Drug Action Network (AIDAN), The South Centre, and Third World Network for attending meetings addressing promotion of access to medicines and affordability.

Reviewer Expertise: Pharmaceutics, drug and antigen delivery systems, innate immunity, tuberculosis, access to medicines, drug regulation, pharmaceutical policy

I confirm that I have read this submission and believe that I have an appropriate level of expertise to confirm that it is of an acceptable scientific standard. 
The benefits of publishing with F1000Research:

- Your article is published within days, with no editorial bias

- You can publish traditional articles, null/negative results, case reports, data notes and more

- The peer review process is transparent and collaborative

- Your article is indexed in PubMed after passing peer review

- Dedicated customer support at every stage

For pre-submission enquiries, contact research@f1000.com 